\title{
The National Petroleum Reserve-Alaska (NPRA) Data Archive
}

\section{Introduction}

The area currently known as the National Petroleum Reserve-Alaska (NPRA, fig. 1) was originally designated in 1923 as Naval Petroleum Reserve No. 4 (NPR-4). It was one of four U.S. regions thought to contain significant amounts of oil that were to be reserved for national crises. Geographic and geologic knowledge of the NPR-4 was only superficial in 1923. Earlier exploration, however, had shown that the region contained the ingredients necessary for oil accumulations to exist: source rocks, reservoir rocks, and geologic structures that could trap petroleum. Oil seeps on the coast and the size of the area (some 37,000 square miles, about the size of Indiana) reinforced the notion that significant quantities of petroleum were present.

Since 1923, various exploratory programs have been undertaken in the NPR-4, first by the Navy, then by the U.S. Geological Survey (USGS), and, most recently, by industry. The government programs resulted in the discovery of several small, noncommercial oil and gas deposits and the accumulation of a vast array of data, which have been stored in many locations by several agencies. Although reports and maps documenting these programs have been published, large amounts of the basic data remain in hard-to-access paper copies or deteriorating, old- or outdated-format magnetic tape or poorly archived rock samples.

Recent discoveries of oil near the northeast corner of the NPRA have renewed industry interest. In response to this interest and the initiation of lease sales by the U.S. Bureau of Land Management, the USGS has undertaken a program to ensure availability of the information accumulated since 1923. To the extent possible, these data will be available in digital format.

\section{Exploration History}

For an area intended as a secure source of petroleum, very little was known in 1923 about NPR-4's petroleum potential. Accordingly, the Navy requested that the USGS map and assess the petroleum resources of this area. The task was completed between 1923 and 1926, and results

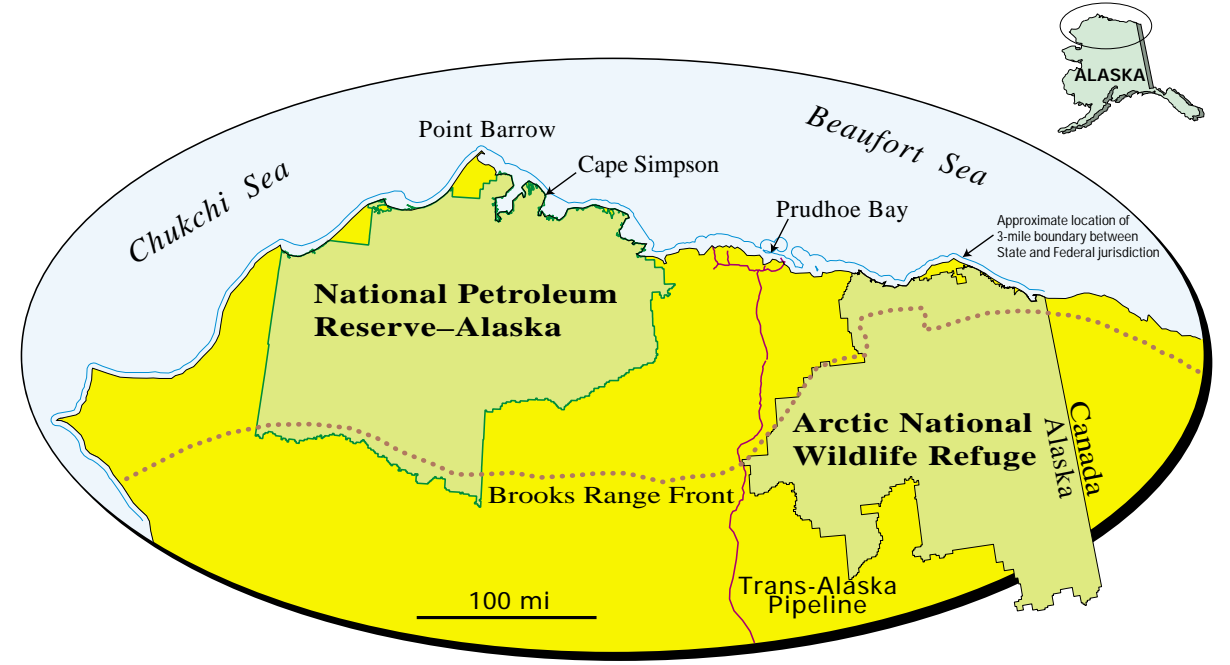

Figure 1. Location of the National Petroleum Reserve-Alaska and the Prudhoe Bay oil field. The North Slope is north of the Brooks Range.

were published in 1930. The report was based on traverses along the larger rivers and reconnaissance-scale maps of the geology and geography. Oil shale source rocks and anticlinal and overthrust structures were documented in the Brooks Range, but prospectors were cautioned about the adverse geographic factors and the consequential high costs. The report recommended drilling near the Cape Simpson oil seepages as the next step in evaluating the petroleum potential, followed by geologic field studies and then additional drilling in areas that appeared favorable.

In 1944, the Navy began a more detailed exploration program that included field mapping, seismic profiling, and aeromagnetic surveys; the geologic component of this work was the responsibility of the USGS. This pioneering effort in Arctic petroleum exploration resulted in the drilling of 45 shallow core tests and 36 test wells. The program ended in 1953 and resulted in the discovery of several small oil and gas deposits. Even though no commercial deposits were found, the vastly improved understanding of the geologic history of northern Alaska served as a foundation for future exploration and established the feasibility of petroleum exploration and production in the Arctic.

Motivated by private industry's 1968 discovery of oil at Prudhoe Bay (the largest oil accumulation in North America) and the oil embargo of 1973, the Navy authorized a new exploration program in the NPR-4.
Between 1974 and 1977, seven test wells were drilled in the northeast corner of the NPR-4; although they followed the trend of Prudhoe Bay, no significant accumulations were found. In 1976, the NPR-4 was redesignated as the NPRA. At the same time, the USGS was charged to assess the oil and gas potential of the NPRA and to discover commercially producible petroleum accumulations. From 1974 to 1982, extensive seismic surveys were conducted (fig. 2), and 28 test wells were drilled, nearly every one of which had shows of oil and gas. Two gas accumulations were discovered that were later turned over to the North Slope Borough to supply the village of Barrow.

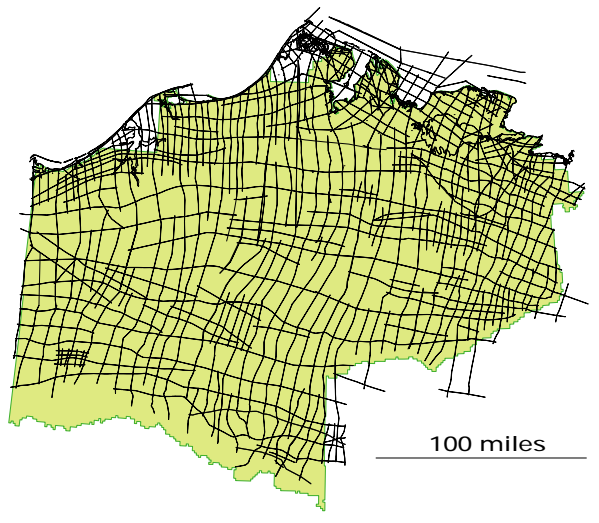

Figure 2. Locations of lines in the NPRA along which seismic data were acquired from 1974 to 1981 as part of the Government exploration program. 


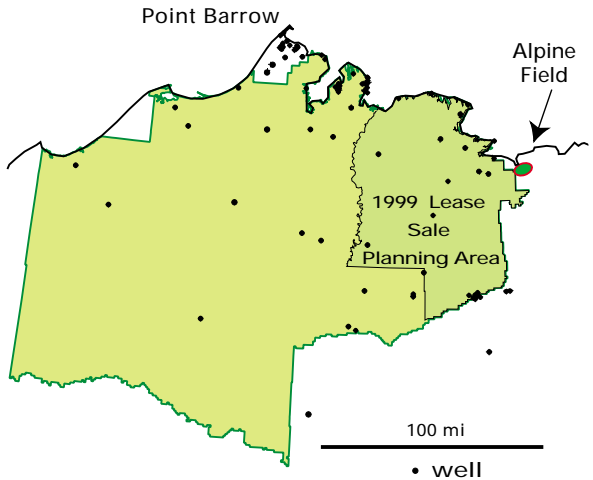

Figure 3. Location of the Alpine oil field, Government-drilled wells, and the 1999 Lease Sale Planning Area in the NPRA.

When the NPRA government exploration program ended in 1982, responsibility for management and protection of the NPRA was transferred to the U.S. Bureau of Land Management. The U.S. Congress authorized competitive oil and gas leasing, and four lease sales were held between 1981 and 1984. One exploratory well was drilled on a lease in 1985; it was a dry hole.

\section{Technological Advances}

In the two decades following the 1968 discovery of the Prudhoe Bay oil field, exploration focused on similar-scale, multibillion-barrel fields because fields containing less than a billion barrels were not economically viable then. In the past 15 years, technological advances - notably 3-D seismic profiling, sequence stratigraphy (a relatively new technique of geologic analysis), and advances in well-site development-have reduced the costs of exploration and development to the point that now fields as small as 100 million barrels that are tens of miles from infrastructure may be economic. Exploration has increased on the North Slope of Alaska in recent years, and several small but viable fields have been discovered, including the 429-million-barrel Alpine field (fig. 3).

With this discovery in 1994, industry interest in the NPRA increased, and the Federal Government reopened part of the NPRA to leasing in 1999.

\section{Data Archive Problems}

The Federal Government archives all data from Government exploration in the NPRA. Until recently, this archive existed in a variety of forms in many locations; accessing it in any organized way was impossible. This material was in danger of being misplaced or deteriorating to a point that it was no longer usable. The data consist of the following:
- Demultiplexed seismic-reflection data collected along about 15,000 line-miles. The data and supporting files are on about 3,500 9-track tapes and are accompanied by about 14,000 pages of paper documents.

- Processed seismic data and supporting files on about 1,000 9-track tapes.

- Drill records for more than 100 wells and including 745 mylar well logs. These records occupy seven file cabinets.

- More than 1,400 geologic reports, maps, and cross sections.

- About 10,000 feet of drill core, which represents about 2 percent of the total footage $(500,000 \mathrm{ft})$ of wells drilled in the NPRA. A split of about half of the 10,000 feet of core is in the USGS Core Research Center in Denver, Colo. The complete set of cores is at the Alaska Geologic Materials Center, Eagle River, Alaska.

- Aeromagnetic and gravity data, which were available largely as paper records consisting of interpretive maps and data tables.

The 9-track seismic data are 20 or more years old; over time, tapes deteriorate, are misplaced, or are separated from the paper documentation. Well logs on mylar and related paper drilling records are accessible only by one person at a time and thus have limited use. The well cores are unprocessed and are not easily accessible by USGS or other scientists.

\section{Data Rescue}

The USGS is capturing, cataloging, and archiving the data to make them readily available in a usable form to USGS scientists and the public. Rescue methods for different types of data are described below:

- Digital seismic data, supporting files, and paper documentation.-The digital seismic data are being copied from the original 9-track tapes to compact discs (CD's). The paper documentation is being scanned and converted to graphic images. These items will be combined with the ASCII supporting files on CD and organized by acquisition year and seismic line identifier.

- Drill records and geologic reports, maps, and cross sections.-Drill records, reports, maps, and cross sections are being converted to graphic images and stored on CD.

- Mylar well logs.-The mylar well logs are being scanned and converted to graphic image files with appropriate log curves selected and digitized into Log ASCII Standard (LAS)-format digital well logs. Both the images and the digital well logs are being cataloged and archived on CD.

- Drill cores.-The drill cores are being slabbed, photographed, cataloged, and archived at the USGS Core Research Center in Denver, Colo.

- Aeromagnetic and gravity data.-The data files are being scanned and converted to graphic images or transcribed into spreadsheets or data bases. The data are cataloged and stored on CD.

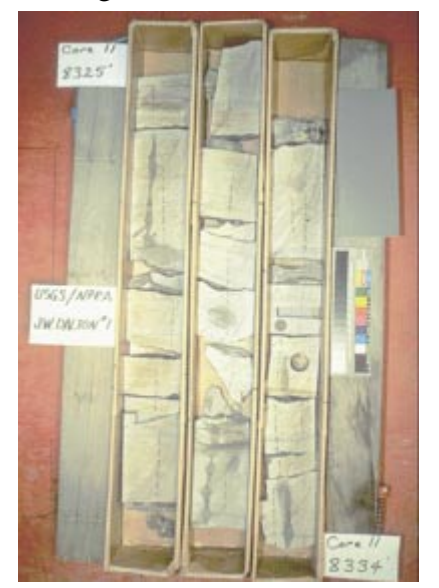

Figure 4. Drill core photograph from USGS Open-File Report 99-015.

The first rescued information is available in USGS Open-File Report 99-015, Selected Data from Eleven Wildcat Wells in the National Petroleum Reserve in Alaska. The CD contains the following information:

- Drill core photographs (fig. 4)

- Depths to selected stratigraphic horizons

- Geologic and drilling reports, scanned from originals

- LAS-format core gamma ray data

- LAS-format borehole log data

- Permeability, porosity, and grain-density data

Open-File Report 99-015 also contains full reference information, including metadata and sources of all information on the CD. The information is accessible through commonly used web browsers and text readers. Future publication plans include a combination of CD's and Internet access to the complete NPRA data set.

For more information, please contact:

Kenneth J. Bird

U.S. Geological Survey

345 Middlefield Road, MS 969

Menlo Park, CA 94025

E-mail: kbird@usgs.gov

Telephone: 650-329-4907 